\title{
PELATIHAN DAN WORKSHOP PENGELOLAAN KOPERASI SEKOLAH DI SMP DAN SMA AL-GHOZALI PASEREAN AROSBAYA
}

\author{
Rizky Wahyudha Rosiawan', Adi Lukman Hakim², Erna Nur Faizah ${ }^{3}$, Mega Barokatul \\ Fajri $^{4}$ \\ ${ }^{1,2,3,4)}$ Program Studi Manajemen, Fakultas Ekonomi, Universitas Muhammadiyah Lamongan \\ e-mail: rwahyuda96@gmail.com
}

\begin{abstract}
Abstrak
Setiap sekolah telah ditetapkan supaya memiliki koperasi sekolah, selain untuk mendidik siswa dalam mengembangkan periaku mandiri, koperasi sekolah merupakan salah satu persyaratan untuk akreditasi dan setiap sekolah pasti memiliki koperasi sekolah. Namun hal tersebut tidaklah demikian, sebagai sekolah yang baru saja berdiri pada tahun ini, SMA Al-Ghozali Paserean masih belum memiliki koperasi sekolah dan tentunya memerlukan sebuah sosialisasi atau workshop mengenai koperasi sebalum mendirikan koperasi di sekolahnya. Hal tersebut dikarenakan sekolah pastinya memerlukan sebuah gambaran tentang koperasi mulai dari definisi koperasi, tujuan serta bagaimana cara mengelola koperasi sekolah. Metode pelaksanaan pada kegiatan ini dimulai dengan tahap persiapan yang terdiri dari koordinasi dan penentuan jadwal serta tempat kegiatan. Selanjutnya yaitu dilanjutkan dengan workshop tentang koperasi sekolah, setelah itu pelatihan tentang pendirian koperasi sekolah mulai dari tata cara rapat, penentuan struktur organisasi koperasi, penamaan serta pengajuan berdirinya koperasi. Yang terakhir adalah dengan melakukan evaluasi kepada para peserta mengenai pemahaman tentang koperasi sekolah.Dalam pelaksanaan pengamas ini para pelaksana dapat membuat para siswa/i dan guru di SMA AL-Ghozali Paserean mengerti tentang koperasi sekolah melalui evaluasi yang dilakukan dengan memberikan soal yang berisi pertanyaan tentang materi yang disampaikan. Sehingga para pihak di SMA Al-Ghozali memiliki keinginan untuk mendirikan koperasi sekolah pada tahun depan dikarenakan untuk tahun ini sekolah tersebut masih ingin fokus dalam pembangunan serta pengadaan perlengkapan sekolah.
\end{abstract}

Kata Kunci: Pelatihan, Pengelolan, Koperasi Sekolah

\begin{abstract}
Each school has been determined to have a school cooperative, in addition to educating students in developing independent behavior, school cooperatives are one of the requirements for accreditation and every school must have a school cooperative. However, this is not the case, as a school that was just established this year, SMA Al-Ghozali Paserean still does not have a school cooperative and of course, requires socialization or workshop on cooperatives before establishing a cooperative in its school. This is because schools certainly need an overview of cooperatives starting from the definition of cooperatives, their objectives, and how to manage school cooperatives. The method of implementation in this activity begins with a preparatory stage consisting of coordination and determining the schedule and location of the activity. Furthermore, it was continued with a workshop on school cooperatives, after which training on the establishment of school cooperatives starting from meeting procedures, determining the organizational structure of cooperatives, naming, and proposing the establishment of cooperatives. The last is by evaluating the participants regarding their understanding of school cooperatives. In implementing this PKM, the implementers can make students and teachers at AL-Ghozali Paserean High School understand about school cooperatives through evaluations carried out by providing questions containing questions about material delivered. So that the parties at Al-Ghozali High School have a desire to establish a school cooperative next year because this year the school still wants to focus on the construction and procurement of school equipment.
\end{abstract}

Keywords: Training, Management, School Cooperatives 


\section{PENDAHULUAN}

Berdasarkan Undang-undang No. 25 Tahun 1992 tentang Perkoperasian, Koperasi adalah badan usaha yang beranggotakan orang-seorang atau badan hukum Koperasi dengan melandaskan kegiatannya berdasarkan prinsip Koperasi sekaligus sebagai gerakan ekonomi rakyat yang berdasar atas asas kekeluargaan. Koperasi memiliki tujuan untuk mensejahterakan anggotanya, koperasi merupakan sebuah lembaga ekonomi yang sangat penting untuk diberdayagunakan, hal tersebut dikarenakan koperasi merupakan sebuah alat bagi orang-orang yang ingin meningkatkan taraf hidupnya. Menurut Hendar dalam Rachmawati, dkk (2019), Dasar kegiatan koperasi adalah kerjasama yang dianggap sebagai cara untuk memecahkan berbagai persoalan yang mereka hadapi masing-masing, oleh sebab itu sudah selayaknya apabila koperasi menduduki yang penting dalam sistem perekonomian suatu negara.

Menurut Lindawati dan Suyanto (2015), dengan mengutip dari pendapat Subandi yang menyatakan bahwa koperasi memiliki tiga asas yaitu: (1) Landasan idiil yaitu landasan yang menentukan arah perjalanan usaha koperasi dan merupakan pandangan hidup serta cita-cita yang ingin dicapai. (2) Landasan struktural yaitu suatu landasan yang berdasarkan aturan-aturan atau tata tertib yang sudah disepakati bersama dan menjadi cita-cita moral yang didasarkan pada falsafah bangsa. (3) Asas koperasi yakni suatu tindakan yang dilakukan oleh seluruh anggota dalam melaksanakan kegiatan koprasi yang dilakukan dengan rasa kekeluargaan dan gotong royong untuk mencapai kesejahteraan bersama. Dari pendapat tersebut maka dalam pelaksanaannya, koperasi memerlukan sebuah tindakan yang nyata dari anggotanya dan tindakan-tindakan tersebut harus sesuai dengan asas koperasi tersebut. Hal tersebut didukung oleh pendapat Hendrojogi dalam Rachmawati, dkk (2019), Prinsip koperasi merupakan landasan pokok koperasi dalam menjalankan usahanya sebagai badan usaha dan gerakan ekonomi rakyat. Prinsip tersebut adalah kemandirian, keanggotaan bersifat terbuka, pengelolaan dilakukan secara demokratis, pembagian sisa hasil usaha dilakukan secara adil sebanding dengan besarnya jasa usaha masing-masing anggotanya, pemberian balas jasa yang terbatas terhadap modal, pendidikan perkoperasian dan kerjasama antara koperasi (Rachmawati, dkk ,2016).

Selanjutnya, tujuan koperasi berdasarkan pasal 3 Undang-undang No. 25 Tahun 1992 adalah untuk meningkatkan kesejahteraan anggotanya, meningkatkan kesejahteraan masyarakat, dan turut serta dalam membangun tatanan perekonomian Indonesia. Dalam hal ini, sejahtera tersebut merupakan sebuah kondisi ketika masyarakat sudah mampu dalam memenuhi kebutuhan hidupnya dan sudah mandiri dalam pemenuhan kebutuhan hidupnya. Kemandirian tersebut hendaknya ditanamkan dalam usia dini melalui pendidikan atau kegiatan koperasi disekolah. Hal tersebut didukung oleh pendapat dari Sukidjo, dkk (2016) yang menyatakan jika dengan ditanamkannya karakter kemandirian sejak usia dini maka ketika menginjak usia dewasa di dalam diri seorang warga negara tersebut akan tertanam jiwa kreativitas dan memiliki kemampuan untuk menemukan inovasi-inovasi baru yang diharapkan dapat menyelesaikan masalah yang ada dalam kehidupan sehari-hari.

Selanjutnya menurut Sukidjo, Muhson. Ali, dan Mustofa (2016), menyatakan jika sekolah merupakan salah satu lembaga yang bertanggungjawab untuk mengembangkan perilaku kemandirian yang akan diwujudkan terhadap siswa melalui Koperasi Sekolah atau Koperasi Siswa (Kopsis). Setiap sekolah telah ditetapkan supaya memiliki koperasi sekolah, selain untuk mendidik siswa dalam mengembangkan periaku mandiri, koperasi sekolah merupakan salah satu persyaratan untuk akreditasi dan setiap sekolah pasti memiliki koperasi sekolah. Namun hal tersebut tidaklah demikian, sebagai sekolah yang baru saja berdiri pada tahun ini, SMP dan SMA Al-Ghozali Paserean Arosbaya masih belum memiliki koperasi sekolah dan tentunya memerlukan sebuah sosialisasi atau workshop mengenai koperasi sebalum mendirikan koperasi di sekolahnya. Hal tersebut dikarenakan sekolah pastinya memerlukan sebuah gambaran tentang koperasi mulai dari definisi koperasi, tujuan serta bagaimana cara mengelola koperasi sekolah.

Berdasarkan Analisis situasi di atas, maka para dosen dari Program Studi Manajemen Fakultas Ekonomi dan Bisnis di Universitas Muhammadiyah Lamongan berkeinginan untuk melakukan pelaksanaan Tridarma Perguruan Tinggi berupa Pengabdian kepada Masyarakat. Adapun tujuan diadakannya kegiatan pengabdian pada masyarakat ini adalah sebagai Pelaksanakan Tri Dharma Perguruan Tinggi, Merealisasikan program kerja Program Studi Manajemen Fakultas Ekonomi dan 
Bisnis di Universitas Muhammadiyah Lamongan dan Meningkatkan pengetahuan, pemahaman dan keterampilan dalam pengelolaan koperasi di SMP dan SMA Al-Ghozali Paserean.

\section{METODE}

\section{Gambar 1. Metode Pelaksanaan}

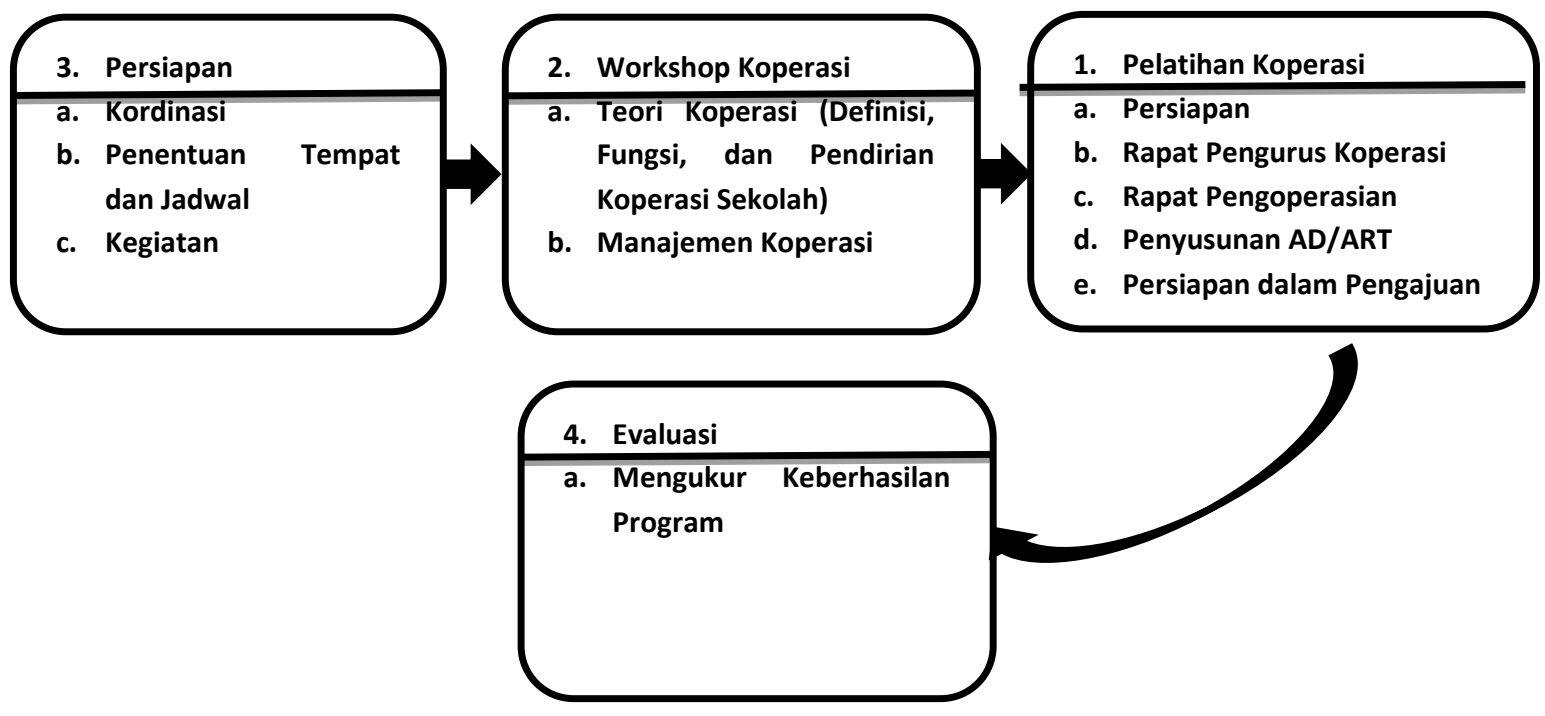

\section{Keterangan Kegitan:}

1. Persiapan:

Langkah tersebut dilakukan karena berkaitan dengan penentuan jadwal dan tempat supaya pihak Yayasan/Sekolah bisa menyesuaikan dan tidak mengganggu KBM di SMP/SMA AL-GHOZALI Paserean Arosbaya.

2. Workshop Koperasi:

Langkah seanjutnya yaitu penyampaian materi tentang koperasi dengan rincian nara sumber sebagai berikut:

Erna Nur Faizah, S.E., M.M

: Pengantar Koperasi

Rizky Wahyudha Rosiawan, S.E., M.M : Teori Koperasi

Adi Lukman Hakim, S.E., M.M : Manajemen Koperasi

Mega Barokatul Fajri, S.E., M.M : Pelatihan Koperasi

3. Pelatihan Koperasi

Persiapan:

Berisi tentang pembentukan panitia pendirian koperasi sekolah dan struktur organisasi koperasi

Rapat Pengurus:

Pembentukan pengurus koperasi mulai dari pembina, ketua hingga pengurus dalam koperasi tersebut

Rapat Pengoperasian:

Rapat yang dilakukan oleh para pengurus mulai dari sistem permodalan, pengelolaan kegiatan, jenis usaha dan barang pendukung yang dibutuhkan

Penyusunan AD/ART:

Hal tersebut dilakukan supaya koperasi memiliki tata kehidupan koperasi mulai dari daftar nama pendiri koperasi, nama koperasi, tempat kedudukan, maksud dan tujuan serta berbagai ketentuan lain terkait keanggotaan

Persiapan Dalam Pengajuan:

Dalam hal ini yaitu mempersiapkan berkas pengajuan pengesahan koperasi ke pihak terkait 
4. Evaluasi

Pengukuran Keberhasilan Program

Dalam hal ini para dosen akan tetap mendampingi dan mengevaluasi terhadap pemahaman para siswa/i tentang materi dan pelatihan yang sudah diberikan. Serta timbal balik dari pengajuan pengesahan kepada dinas terkait.

\section{HASIL DAN PEMBAHASAN}

Selanjutnya, dengan beracuan pada target yang sudah ditentukan maka penulis akan menyampaikan laporan dari hasil PKM ini berdasarkan metode yang sudah ditetapkan pada Bab 3 diatas yaitu:

1. Tahap persiapan

Tahap perispan tersebut berisikan beberapa jenis kegiatan yaitu:

a. Kordinasi : kordinasi tersebut dilakukan di pondok pesantren AL-Ghozali paserean bersama dengan pengurus yayasan, para kepala sekolah, serta dewan guru untuk berdiskusi mengenai acara yang akan dilaksanakan

b. Penentuan Tempat dan Jadwal Kegiatan: dalam tahap ini untuk penentuan tempat dan jadwal kegiatan melalui rapat kordinasi tersebut, dikarenakan untuk menyesuaikan waktu yang pas supaya tidak mengganggu kegiatan di lingkungan pondok pesantren AL-Ghozali paserean. Sehingga untuk Tempat dilaksanakan di aula pondok pesantren al-ghozali paserean dan untuk waktu kegiatan menuai sebuah kesepakatan untuk diadakan selama 2 hari para tanggal 12-13 September 2020.untuk workshop diadakan pada tanggal 12 dan untuk pelatihan serta evaluasinya dilakukan pada tanggal 13 september 2020.

2. Workshop Koperasi

Pada tahap ini, kegiatan diawali dengan acara pembukaan, dan sambutan yang disampaikan oleh pihak yayasan dan kepala sekolah sekaligus pembukaan acaranya.

Selanjutnya kegiatan dilanjutkan dengan penyampaian materi tentang Pengantar Koperasi yang disampaikan oeleh Erna Nur Faizah, S.E., M.M, materi kedua dilanjutkan dengan materi mengenai manajemen koperasi yang disampaikan oleh Rizky Wahyudha Rosiawan, S.E., M.M Dra. Ninik Widiyanti yang diterbitkan pada tahun 2004. Materi yang terakhir disampiakan oleh Adi Lukman Hakim, S.E., M.M yaitu tentang apa itu pengembangan sumber daya manusia pada koperasi yang berdasarkan kepada Surat Keputusan Menteri Tenaga Kerja, Transmigrasi dan Koperasi No 638/SKPT/Men/1974, tentang Ketentuan Pokok Pendirian Koperasi Sekolah. Setelah dilakukan workshop, maka dihari keduanya dilaksanakan pelatihan koperasi sekolah, kegiatan tersebut dibimbing oleh Mega Barokatul Fajri, S.E., MBA

Setelah para pemateri memberikan penjelasan, maka para peserta diberikan kesembatan untuk mengajukan beberapa pertanyaan yang berkenaan dengan koperasi sekolah. Untuk partisipasi peserta dalam mengikuti kegiatan dan tanggapan mengenai materi yang disampaikan sangatlah besar.

3. Pelatihan Koperasi

Selanjutnya, pada kegiatan pelatihan koperasi di hari kedua, untuk partisipasi dari para peserta sangatlah tinggi, mereka sangatlah antusias dalam mengikuti semua rangkaian kegiatan pada pelatihan ini mulai dari Persiapan yang berisikan tentang pembentukan panitia pendirian koperasi sekolah dan struktur organisasi koperasi, Rapat Pengurus:

Pembentukan pengurus koperasi mulai dari pembina, ketua hingga pengurus dalam koperasi tersebut, Rapat Pengoperasian: yang dilakukan oleh para pengurus mulai dari sistem permodalan, pengelolaan kegiatan, jenis usaha dan barang pendukung yang dibutuhkan, Penyusunan AD/ART: Hal tersebut dilakukan supaya koperasi memiliki tata kehidupan koperasi mulai dari daftar nama pendiri koperasi, nama koperasi, tempat kedudukan, maksud dan tujuan serta berbagai ketentuan lain terkait keanggotaan, yang terakhir tentang Persiapan Dalam Pengajuan: Dalam hal ini yaitu mempersiapkan berkas pengajuan pengesahan koperasi ke pihak terkait

4. Evaluasi

Dalam hal ini, untuk mengetahui tentang pemahaman para peserta mengenai ruanglingkup materi yang disampaikan, maka dibuatlah sebuah ujian tertulis. Untuk ujian tertulis disajikan beberapa pertanyaan mengenai materi dan seluruh kegiatan yang telah disampaikan. Dari hasil 
ujian tertulis tersebut mayoritas para peserta memahami tentang seluruh materi yang sudah diberikan.

Mengenai pendirian di koperasi sekolah, untuk tahun ini pihak sekolah masih belum bisa karena dari pihak sekolah masih ingin fokus dalam hal pembangunan serta pengadaan perlengkapan sekolah dikarenakan SMP dan SMA AL-Ghozali Paserean masih baru berdiri. Namun dari pihak sekolah sangatlah ingin jika disekolahnya berdiri Koperasi sekolah yang dikelola oleh siswa dan guru guna meningkatkan kesejahteraan di lingkungan SMP dan SMA AL-Ghozali paserean Arosbaya.

Tabel 2 Jumlah Peserta

\begin{tabular}{|c|c|c|}
\hline Jenjang & Kelas & Jumlah Siwa/i \\
\hline SMP & VII & 15 \\
\hline SMA & X & 18 \\
\hline SMP dan SMA & Guru & 6 \\
\hline \multicolumn{2}{|c|}{ Total } & 39 \\
\hline
\end{tabular}

Gambar 1 Kegiatan Workshop dan Pelatihan Koperasi Sekolah
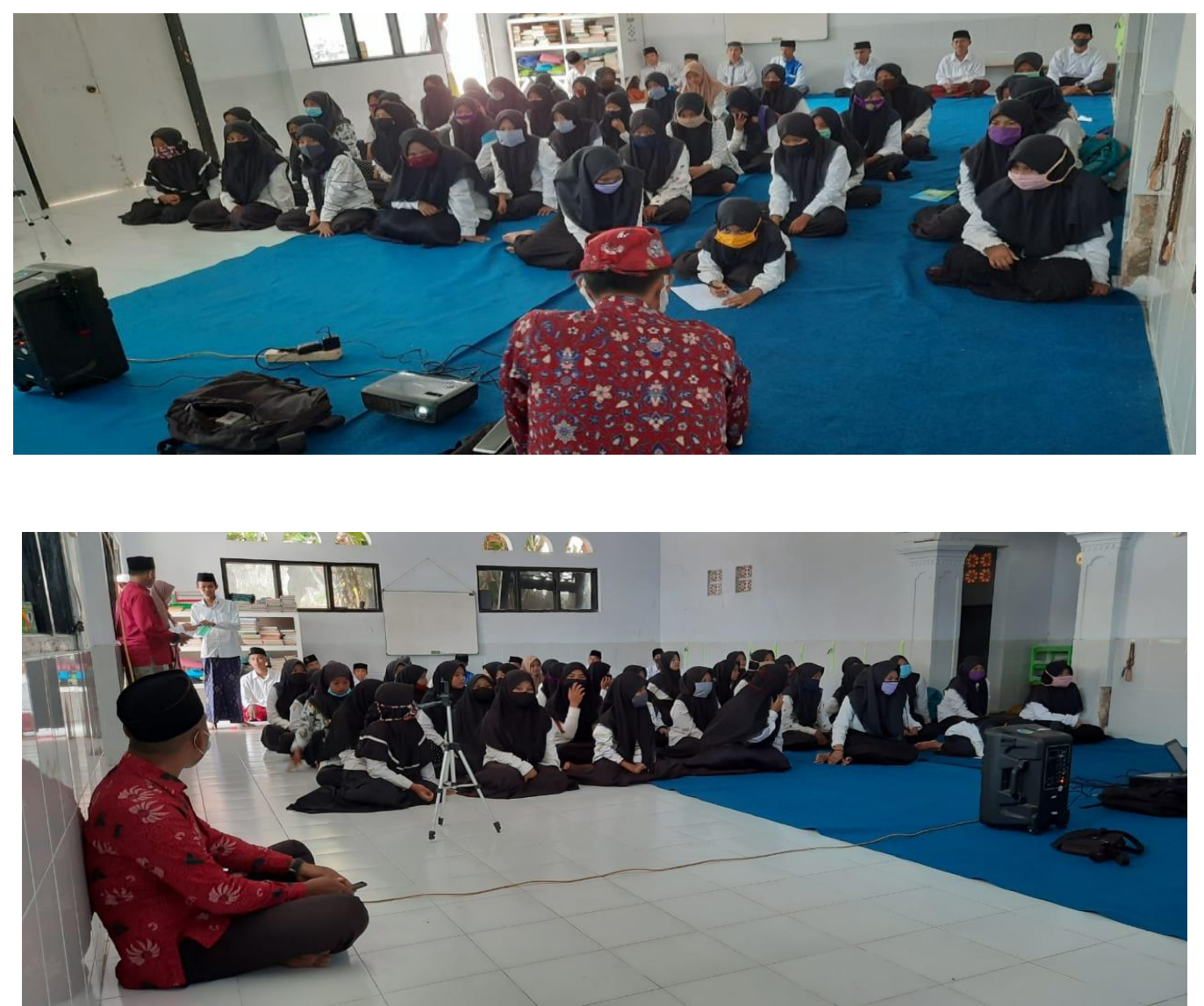

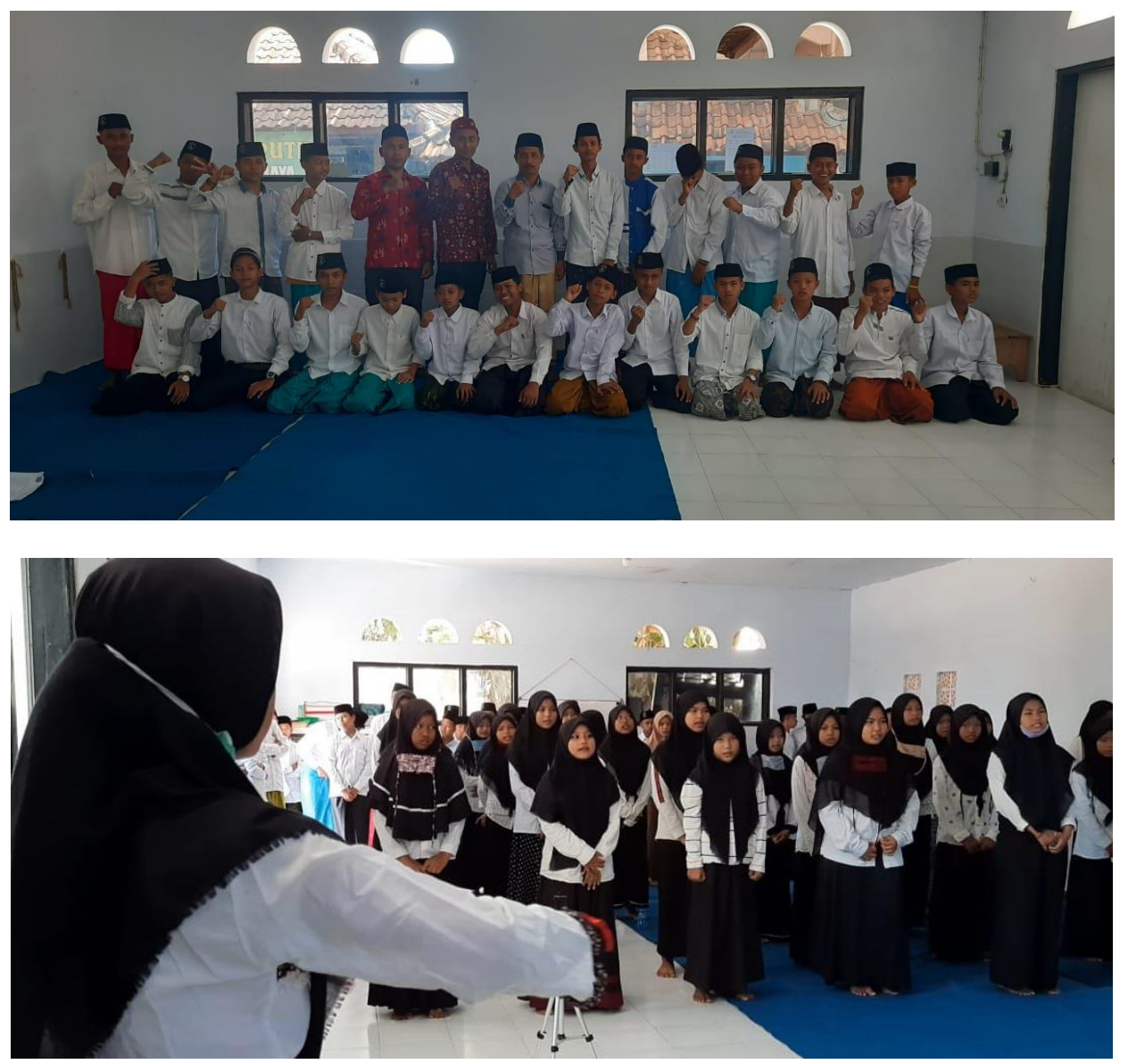

\section{SIMPULAN}

Pengabdian masyarakat ini dilaksanakan dan diselesaikan berdasarkan prosedur yang dengan sebenar-benarnya dan diharapkan dapat memberikan kontribusi dalam ilmu pengetahuan para siswa, guru dan juga seluruh pihak sekolah. Kegiatan pengabdian kepada masyarakat yang dilaksanakan pada tanggal 12 - 13 September 2020 dengan tema Workshop \& Pelatihan Koperasi Sekolah pada SMP dan SMA AL-Ghozali Paserean ini juga dapat meningkatkan profesionalisme dosen pada lingkungan Program Studi Manajemen Fakultas Ekonomi Universitas Muhammadiyah Lamongan sehingga dapat menambah wawasan peserta didik khususnya guru dan siswa di SMP dan SMA AL-Ghozali Paserean. Harapannya kegiatan ini dapat terus dilaksanakan secara berkelanjutan guna memberikan pengetahuan dan memperdalam pengetahuan atau pemahaman guru dan siswa tentang bagaimana berkoperasi dan peningkatan kesejahteraan anggota koperasi (Rachmawati, dkk, 2019).

\section{SARAN}

Berdasarkan hasil penelitian, yang diharapkan dapat memberikan masukan pemikiran yang digunakan sebagai usaha untuk menambah ilmu pengetahuan dalam bidang pendidikan, khususnya dalam kegiatan koperasi, saran yang dapat peneliti sumbangkan sebagai berikut:

1. Teoritis, Penelitian ini diharapkan dapat memberikan masukan dan saran yang sangat besar terhadap kajian ilmiah selanjutnya yang berkaitan tentang manajemen koperasi sekolah di SMP dan SMA Al-Ghozali Paserean Arosbaya. 2. Praktis: yang pertama bagi pihak sekolah, Saran untuk pihak sekolah adalah, supaya koperasi sekolah segera terbentuk karena jika dilihat dari antusias para guru dan siswa mereka sangat tertarik untuk pendirian koperasi sekolah tersebut. yang kedua bagi siswa, Saran yang di dapat oleh siswa yaitu menyadarkan dan memberikan motoivasi bagi para siswa sekolah (anggota koperasi) sehingga siswa - siswi akan aktif dalam organisasi koperasi sekolah yang ada, selain itu peneliti juga dapat menjadikan pijakan bagi koperasi sekolah, sekaligus bahan koreksi, sehingga mampu memberikan motivasi kepada anggota 
koperasi (peserta didik) untuk lebih memberdayakan koperasi dan harapan penelitian ini dapat memberikan masukan bagi koperasi yang akan datang.

\section{UCAPAN TERIMA KASIH}

Ucapan terimakasih disampaikan kepada pihak sekolah karena sudah diberikan kesempatan untuk kami para dosen Prodi Manajemen Fakultas Ekonomi dan Bisnis Universitas Muhammadiyah Lamongan untuk membagi ilmu di SMP dan SMA AL-Ghozali Paserean Arosbaya. Selanjutnya terimakasih juga atas fasilitas yang sudah diberikan seperti Tempat dan proyektor. Untuk LPPM Universitas Muhammadiyah Lamongan, Terimakasih atas diterimanya proposal pengabmas kami dan juga karena telah memberikan kesempatan dan izin kepada kami untuk melaksanakan pengabmas ini.

\section{DAFTAR PUSTAKA}

Lindawati. Lilis, Suyanto. 2015. Peran Koperasi Sekolah Dalam Meningkatkan Sikap Kewirausahaan Siswa SMK Negeri 1 Wonogiri. Harmoni Sosial: Jurnal Pendidikan IPS. Volume 2, No 2, September 2015 (170-180)

Rachmawati, D.W, dkk. 2019. Pelatihan dan Workshop Pengelolaan Koperasi di Sekolah. CARADDE: Jurnal Pengabdian Kepada Masyarakat. Volume 1. Nomor 2

Rifa'I, M. N, Rusmiati, dan Mursilah. 2017. Analisis MAanajemen Koperasi Sekolah Di SMK Taqwa Belitang. UTILITY: Jurnal Ilmiah Pendidikan dan Ekonomi. Volume 1, No. 2.

Sukidjo, Muhson. Ali, dan Mustofa. 2016. Koperasi Sekolah Sebagai Wadah Pengembangan Karakter Siswa. Jurnal Economia, Volume 12, Nomor 2, Oktober 2016 